\title{
THE IMAGO DEI (GEN 1:26-27): A HISTORY OF INTERPRETATION FROM PHILO TO THE PRESENT
}

\section{Daniel Simango}

North-West University, Potchefstroom campus

Unit for Reformed Theology and Development of the SA Society

Principal of the Bible Institute of South Africa, Kalk Bay, Cape Town

danielsimango@outlook.com

\section{ABSTRACT}

The purpose of this article is to present a history of interpretation of the image and likeness of God (Gen 1:26-27) from Philo to the present. The article presents the various interpretations given, the reasons for their interpretations and changes in the major interpretation over time.

Keywords: Imago Dei; image of God; Genesis 1:26-27; history of interpretation; from Philo to the present

\section{INTRODUCTION}

Because of the large volume of material available, and the broadness of the subject, this article is selective in the use of material from the time of Philo to the present, giving a brief summary of the history of interpretation of the image and likeness of God (Gen 1:26-27). The article shows the various interpretations given, the reasons for their interpretations and changes in the major interpretation over time. Gunnlaugur A. Jónsson gives a comprehensive survey of how the image and likeness of God have been interpreted from 1882-1982. ${ }^{1}$ David J.A. Clines, ${ }^{2}$ J.M. Miller, ${ }^{3}$

1 Jónsson, Gunnlaugur. A. 1988. The image of God: Genesis 1:26-28 in a century of Old Testament research. Lund: Almqvist and Wiksell.

2 Clines, D.J.A. 1968. The image of God in man. Tyndale Bulletin 19: 54-61.

3 Miller, J.M. 1972. In the image and likeness of God. Journal of Biblical Literature (JB). 91: 289304.

\section{UNISA}


Anthony Hoekema, ${ }^{4}$ and Claus Westermann ${ }^{5}$ give shorter surveys of the history of interpretation of the image and likeness of God in Genesis 1:26-27.

\section{PHILO}

The following discussion dealing with Philo's view on the image of God (Gen 1:26-27) is based on De Lacey's research. ${ }^{6}$ Philo refers to the image of God in his discussion of the logos. Within Philo's framework of ideas, man is not himself the image of God, but he is created 'after' or 'according to it'. ' When it comes to the interpretation of the image and likeness of God, Philo distinguishes between the man of Genesis 1:26-27 and the man of Genesis 2:7, the former being a platonic ideal and the latter, the concrete species of mankind. Philo equates the ideal man with the logos which comes close to identifying man with the image, but he does not explicitly identify man with the image or logos because he strongly believes that God cannot be conceived of as physical. ${ }^{8}$ According to Philo, the image consists of the mind or reason, which is spoken of in terms of a divine spirit breathed by the Maker into the individual. ${ }^{9}$ Philo's interpretation of the image and likeness of God in Genesis 1:26-27 is based on Greek philosophy. Philo was influenced by the Greek philosopher Plato. He makes no reference to the Scriptures when he explains what the image of God is.

\section{IRENAEUS (D. CA 200 AD)}

Irenaeus' view of humanity was that 'man is a mixed organisation of soul and flesh, who was formed after the likeness of God and modelled by His hands - that is, by the Son and Holy Spirit, to whom also He said, 'Let Us make man [Gen 1:26]'. ${ }^{10}$ According to Irenaeus, unbelievers who are made in God's image possess a twofold nature: body and soul. Believers, however, who are made in God's image and likeness, possess a three-fold nature: body, soul, and spirit. The Holy Spirit is missing in the

4 Hoekema, A. 1986. Created in God's image. Grand Rapids: Eerdmans, 33-65.

5 Westermann, C. 1987. Genesis 1-11: A commentary. Minneapolis: Augsburg, 148-158.

6 De Lacey, D.R. 1979. Image and incarnation in Pauline Christology: A search for origins. Tyndale Bulletin (TB) 30: 12-15.

7 Philo. 1993. The works of Philo (New updated edition, complete and unabridged in one volume). Peabody: Hendrickson, 5, 61, 247. See also De Lacey, D.R. 1979. Image and incarnation in Pauline Christology: A search for origins. Tyndale Bulletin (TB) 30: 3-28.

8 Philo. 1993. The works of Philo (New updated edition), 10-11, 298-281. See also De Lacey, D.R. 1979. Image and incarnation in Pauline Christology, 14.

9 Philo. 1993. The works of Philo, 10-11, 27. See also De Lacey, D.R. 1979. Image and incarnation in Pauline Christology, 13; McCasland, S.V. 1950. The image of God according to St. Paul. Journal of Biblical Literature (JBL) 69: 85-100.

10 Irenaeus. 1953. Against Heresies. In Ante-Nicene Fathers. Edited by A. Roberts and J. Donaldson. Grand Rapids: Eerdmans, 1: 463. 
soul of the unbeliever, therefore the unbeliever is a carnal person, he is an imperfect being, and he possesses the image [of God] in his formation but does not receive the likeness [of God] through the Spirit. ${ }^{11}$ According to Irenaeus, at the fall (Gen 3) man lost his likeness to God and yet he retained the image of God. ${ }^{12}$ Irenaeus views the residual image in man as consisting of man's rational faculty and ability to choose, but in a corrupt way..$^{13}$ Irenaeus views the likeness of God as the 'robe of sanctity', which implies the holiness and righteousness that the Holy Spirit had bestowed on Adam. ${ }^{14}$ In his writings, Irenaeus says that at the fall man lost 'true rationality' and he began to live 'irrationally, opposed the righteousness of God, giving himself over to every earthly spirit and serving all lusts'. ${ }^{15}$ Christ is the one who enables salvation for mankind through his death on the cross. ${ }^{16}$ Through his own blood, Christ restores believers back to the image and likeness of God. ${ }^{17}$

\section{AUGUSTINE (D. CA. 430 AD)}

Augustine's starting point was that man is made in the image of the triune God. The image of God in man is to be found in his soul (i.e. rational or intellectual soul). The image of the Creator, which is immortal, is immortally implanted in its immortality in man. According to Augustine, the mind is Trinitarian in constitution which is composed of memory, understanding, and will. ${ }^{18}$ Augustine views the image of God in Genesis 1:26-27 as the power of reason and understanding set over all irrational creatures:

But the mind must first be considered as it is in itself before it becomes a partaker of God, and His image must be found in it. For, as we have said, although worn out and defaced by losing participation of God, yet the image still remains. For it is His image in this very point, that it is capable of Him; which so great good is only made possible by its being His image. ${ }^{19}$

When man fell, the image of God was corrupted. The participation of the soul in God was lost, but God restores this loss of participation through redemption. The participation in God brings the image to perfection. ${ }^{20}$ Augustine sees Jesus Christ, the first-born of all creation, as the perfect image of God who reflects God perfectly. ${ }^{21}$

11 Irenaeus. 1953. Against Heresies, 1:532.

12 Irenaeus. 1953. Against Heresies, 1:466.

13 Irenaeus. 1953. Against Heresies, 1:466.

14 Irenaeus. 1953. Against Heresies, 1:457.

15 Irenaeus. 1953. Against Heresies, 1:466.

16 Irenaeus. 1953. Against Heresies, 1:444, 542.

17 Irenaeus. 1953. Against Heresies, 1:528.

18 Augustine. 1988. St Augustine: on the Holy Trinity; doctrinal treatises; moral treatises. In PostNicene Fathers. Edited by P. Schaff, Nicene and Grand Rapids: Eerdmans, 3: 142.

19 Augustine. 1988. St Augustine: On the Holy Trinity, 189.

20 Augustine. 1988. St Augustine: On the Holy Trinity, 189.

21 Augustine. 1988. St Augustine: On the Holy Trinity, 98. 
He shares the same likeness with God the Father. In support of his view, Augustine cites Romans 12:1-2 and he points out that the believer's mind is renewed so that he can understand the truth. When the mind of the believer is renewed, he does what is good, acceptable and perfect in the eyes of God. Therefore, 'according to the image of God is a man renewed in the knowledge of God. ${ }^{22}$

\section{THOMAS AQUINAS (1225-1274 AD)}

This discussion on Aquinas' interpretation of the image of God is indebted at many points to Hoekema (1986, 33-35). ${ }^{23}$ Like Irenaeus, Aquinas distinguishes the image and likeness of God in humanity. According to Aquinas, the 'likeness of God' is moral, for human beings were created good. When man fell, sin corrupted the moral likeness to God and perverted the will. Man lost the supernatural grace that God had bestowed upon him in the beginning but did not destroy man's essential identity as a rational being. Aquinas points out that the fallen man needs supernatural grace from God so that his moral likeness may be restored..$^{24}$ In his work, the Summa Theologica (Summary of Theology), Aquinas identifies the image of God primarily in man's rational faculty, intellect, or reason. He points out that rational, intellectual creatures are in the image of God when he says: 'It is clear, therefore, that intellectual creatures alone, properly speaking, are made [according] to God's image. ${ }^{25}$

Aquinas goes on to say that the image of God is found more perfectly in angels than in man, because their intellectual nature is more perfect. ${ }^{26}$ Aquinas views the image of God in three senses. Firstly, the general sense of the image of God is seen in all people because of their rational faculty. Secondly, the richer or higher sense of the image of God is seen only in believers who are being conformed to the grace of God (Christ), though they are imperfect. Thirdly, the highest sense of the image of God is seen in believers who have been glorified. These three senses of the image of God are seen in the following:

Firstly, because man possesses a natural aptitude for understanding and loving God and this aptitude consists in the very nature of the mind, which is common to all men. Secondly, because man actually or habitually knows and loves God, though imperfectly and this image consists in the conformity of grace. Thirdly, because man knows and loves God perfectly and this image consists in the likeness of glory. ${ }^{27}$

22 Augustine. 1961. The confessions of Saint Augustine. London: Penguin, 320-321; Augustine. St Augustine: On the Holy Trinity, 200-201.

23 Hoekema, A. 1986. Created in God's image, 33-35.

24 Aquinas, T. 1952. The Summa Theologica 1. In Great books of the Western world. Edited by H.R. Maynard. London: William Benton. 19: 339.

25 Aquinas, T. 1952. The Summa Theologica 1, 493.

26 Aquinas, T. 1952. The Summa Theologica 1, 493-494.

27 Aquinas, T. 1952. The Summa Theologica 1, 495-496. 
Aquinas' understanding of the image and likeness of God is similar to that of Irenaeus, which probably suggests to us that his view could have been influenced by Irenaeus' writings.

\section{SUMMARY OF PHILO, IRENAEUS, AUGUSTINE, AND AQUINAS' INTERPRETATIONS}

They all interpreted the image of God in man as the power of reason, but the basis of their interpretations is different. Philo's view was strictly influenced by Greek philosophy, while the interpretations of Irenaeus, Augustine and Aquinas were predominantly influenced by the New Testament.

\section{MARTIN LUTHER}

Unlike Irenaeus and Augustine, Luther does not distinguish the image of God from the likeness of God. However, he distinguishes the image of God into two parts: the 'public image' and the 'private image'. In a way, this reminds of the distinction between image and likeness in Irenaeus and Aquinas. The public image is universal among men and it consists of the will and intellect, which has been preserved after the fall. The private image is the original righteousness that has been lost at the fall and can only be restored to believers when they are converted. ${ }^{28}$

When discussing the private image, Luther says that originally human beings were created good, holy, and pure as God himself. ${ }^{29}$ When man sinned (Gen 3) the image of God was corrupted, man became a sinner, though he was not so when he was created (Gen 1:26-27). Luther sees the devil as the great opponent of God because he deceived our first parents and led them to sin against God in Genesis 3. The devil's moral characteristics and works (deception and leading men into sin) contradict God's ultimate will for creation and for man. ${ }^{30}$ Luther points out that human beings, in general, are threatened by the devil at all times and are subject to temptation: therefore the power of God and the power of the devil are opposed to each other. The devil wants to be God and he is 'the ruler of this world' (John 12:31; 14:30). Therefore, Luther sees mankind as either belonging to the kingdom of the devil or to the kingdom of God. ${ }^{31}$ The fallen man is seen to be in the image of the

28 See Brunner, E. 1952. The Christian doctrine of creation and redemption. Philadelphia: Westminster Press, 76; Blocher, H. 1984. In the beginning: The opening chapters of Genesis. Leicester: Inter-Varsity Press, 81.

29 Luther, M. 1958. Luther's works Vol 1: Lectures on Genesis chapters. Edited by J. Pelikan. St. Louis: Concordia, 65; See also Cairns, D. 1953. The image of God in man. London: Collins, 124; and Althaus, P. 1966. The theology of Martin Luther. Philadelphia: Fortress Press, 158.

30 Luther, M. 1958. Luther's works Vol 1: Lectures on Genesis, 150, 158ff; see also Althaus, P.1966. The theology of Martin Luther, 162.

31 Althaus, P. 1966. The theology of Martin Luther, 163. 
serpent or devil (thus the corrupt image) and this is opposite to God-likeness (Gen 1:26-27). We all bear the image of the fallen Adam. ${ }^{32}$

Coming to the New Testament, Luther says that Paul in his letters addresses the private image rather than the public image because it was affected by the fall (Cairns 1953, 122). Redemption restores the shattered image of God (Col 3:10; Eph 4:24). Christ is the heavenly image who restores the corrupted image through redemption. God makes the believer righteous and holy, and he lives in conformity to God's character. ${ }^{33}$ This corrupted image in man will be restored completely on the last day when believers are glorified. ${ }^{34}$

\section{JOHN CALVIN}

Calvin sees the image of God in man primarily in man's soul: 'God's glory shines forth in the outer man, yet there is no doubt that the proper seat of his image is in the soul. ${ }^{35}$ Calvin also points out that our outward physical form distinguishes and separates us from animals. Like Luther, Calvin does not distinguish the two words 'image' and 'likeness.' He says the word 'likeness' was added as a way of explanation of the first word 'image'. This was a common practice or custom among the Hebrews. ${ }^{36}$ Unlike Luther, Calvin does not resort to public and private images. He sees the image and likeness of God (Gen 1:26-27) as consisting of 'righteousness and true holiness'. This interpretation is based on Colossians 3:10 and Ephesians $4: 24 .^{37}$

According to Calvin, the fall affected the image of God in man. The image of God was corrupted or distorted by sin. There is no doubt that Adam, when he fell from his state, was by this defection alienated from God. Therefore, even though we grant that God's image was not totally annihilated and destroyed in him, it was so corrupted that whatever remains is a frightful deformity. ${ }^{38}$

Calvin's conclusion that the image and likeness of God in man was corrupted by the fall is based on the New Testament Scriptures. In the New Testament, Paul teaches that the gospel transforms believers into the image of God, which means that when man sinned, the image of God was corrupted and man became alienated from God. Through sanctification, believers are renewed into the image of Christ. Christ,

32 Luther, M. 1958. Luther's works Vol 1: Lectures on Genesis, 222-223; see also Cairns, D. 1953. The image of God in man, 124.

33 Luther, M. 1958. Luther's works Vol 1: Lectures on Genesis, 64, 68.

34 Luther, M. 1958. Luther's works Vol 1: Lectures on Genesis, 65.

35 Calvin, J. 1960. The institute of the Christian religion. Edited by J.T. McNeill. Philadelphia: Westminster, 186.

36 Calvin, J. 1960. The institute of the Christian religion, 187.

37 Calvin, J. 1960. The institute of the Christian religion, 189; see also Calvin, J. 1979a. Calvin's commentaries Vol 1: Genesis. Grand Rapids: Baker, 94.

38 Calvin, J. 1960. The institute of the Christian religion, 189. 
the true and perfect image of God, restores the believer into the image and likeness of God. ${ }^{39}$ Calvin says that part of the image of God is now being manifested in the elect because they have been born of the Spirit, but they will attain its full splendour in heaven, where they will be glorified ${ }^{40}$ Calvin also points out that the angels are created in the image of God; one day believers will become like them when they are glorified (Matt 22:30). ${ }^{41}$

\section{RECENT COMMENTARIES AND THEOLOGICAL STUDIES}

This section lists the various interpretations of the image of God under the following headings: substantive views, relational views, functional views, and a combination of two or three of these views.

\section{Substantive views}

August Dillman interprets the image and likeness of God in man (Gen 1:26-27) as his mental endowment, power of thought, self-consciousness, freedom of will, capacity for the eternal, the true, and the good. ${ }^{42}$ Dillman points out that man's bodily form, his expression and instrument of the mind, is not to be separated from his spiritual nature; all these are not to be excluded from the concept of the image of God. Like Luther and Calvin, Dillman does not distinguish the two words 'image' and 'likeness'. He says the word 'likeness' has the same meaning as the word 'image', 'but in a cumulative way, to make it more expressly prominent' ${ }^{43}$ When Dillman comes to the New Testament, he sees the concept of the image of God as having a deeper meaning: it denotes the idea of moral-religious perfection. Therefore, the image of God in the New Testament is something that has been destroyed by sin, and only restored and restorable through Christ. ${ }^{44}$

Carl Friedrich Keil and Franz Delitzsch held a similar view. They suggested that the image and likeness of God in Genesis 1:26-27 consist of the spiritual personality of man. They believed that the 'spiritual personality of man' is not

39 Calvin, J. 1960. The institute of the Christian religion, 189. Calvin, J. 1979a; Calvin's commentaries Vol 1: Genesis. Grand Rapids: Baker, 94; Calvin, J. 1979b. Calvin's commentaries Vol XX1: Ephesians. Grand Rapids: Baker, 295-296. Calvin, J. 1979c. Calvin's commentaries Vol 1: Colossians. Grand Rapids: Baker, 211-212.

40 Calvin, J. 1960. The institute of the Christian religion, 190.

41 Calvin, J. 1960. The institute of the Christian religion, 188.

42 Dillman, A. 1897. Genesis: Critically and exegetically expounded. Edinburgh: T. and T. Clark, 80-83. Also cited in. Jónsson, Gunnlaugur. A. The image of God: Genesis 1:26-28, 39.

43 Dillman, A. 1897. Genesis: Critically and exegetically expounded, 80. Also cited in Jónsson, Gunnlaugur, A. The image of God: Genesis 1:26-28, 39.

44 Dillman, A. 1897. Genesis: Critically and exegetically expounded, 82. 
merely to be understood from a psychological perspective, where it is a combination of self-consciousness and self-determination, or a conscious free ego, but on the basis and form of the divine likeness. ${ }^{45}$ The spiritual personality of man consists of the free self-conscious personality, which is 'a creaturely copy of the holiness and blessedness of the divine life' ${ }^{46}$ When man fell, this concrete essence of divine likeness was corrupted by sin. According to Keil and Delitzsch, it is only through Christ that the corrupted divine likeness is restored (Col 3:10; Eph 4:24). Keil and Delitzsch's interpretation of the image of God is based on their understanding of the New Testament.

John Skinner says that the concept of the image of God (Gen 1:26-27) probably originated from Babylonian mythology and he gives examples from Babylonian mythology creation accounts which are similar to Genesis 1:26-27. ${ }^{47}$ According to Skinner, the image and likeness of God denotes primarily the bodily form, but includes spiritual attributes, which he does not describe.

It might be truer to say that it [the image of God] denotes primarily the bodily form, but includes those spiritual attributes of which the former is the natural and self-evident symbol. ${ }^{48}$

Skinner argues that his view is strongly suggested by a comparison of Genesis 5:3 and 5:1: the fact that Seth was in the image and likeness of Adam denotes physical resemblance, therefore the image of God is corporeal or physical in nature. He also asserts that God is said to have a form in the Old Testament and he cites Numbers 12:8 and Psalm 17:15 to support his interpretation. ${ }^{49}$

Like Skinner, Von Rad says that the concept of the image and likeness of God in Genesis 1:26-27 is similar to that of the Oriental myths where a god makes a man (or a god) in his image. ${ }^{50}$ Therefore, the concept should not be detached from its broader connection with Oriental ideas. Von Rad sees the whole man as created in the image and likeness of God and this is not limited to any part of man (i.e. the spiritual, rational, physical characteristics). He argues that man corresponds to God in his totality, but he understands the image of God in a predominantly corporeal sense. He cites Psalm 8:5 to support his view, and he concludes that the image of God in Genesis 1:26-27 does not refer directly to God, but to angels. Like the angels,

45 Keil C.F. and Delitzsch, F. 1978. Commentary on the Old Testament in ten volumes. Volume 1. The Pentateuch: Three volumes in one. Grand Rapids: Eerdmans, 63.

46 Keil C.F. and Delitzsch, F. 1978. Commentary on the Old Testament in ten volumes. Volume 1. The Pentateuch, 64.

47 Skinner, J. 1930. A critical and exegetical commentary on Genesis. International Critical Commentary. Edinburgh: T and T Clark, 31.

48 Skinner, J. 1930. A critical and exegetical commentary on Genesis, 32.

49 Skinner, J. 1930. A critical and exegetical commentary on Genesis, 32.

50 Von Rad, G. 1972. Genesis: A commentary. Old Testament Library. London: SCM Press, 58. 
man has a corporeal or physical body. ${ }^{51}$ Von Rad sees man's commission to rule creation not as belonging to the definition of the image of God, but as a consequence of the image of God (i.e. man can rule over creation because he is created in God's image). ${ }^{52}$

\section{Relational views}

Karl Barth sees the image of God in Genesis 1:26-27 as consisting of both the vertical relationship between man and God and in the horizontal relationship between men. ${ }^{53}$ He says that scholars who have tried to locate the exact substantive qualities in man, which the image of God consists of, have missed the mark. ${ }^{54}$ According to Barth, the relational aspect is seen in the fact that man is created in the image of God, male and female. ${ }^{55}$ Man is capable of having a relationship with God, and other human beings. Therefore, Barth concludes that God created man for fellowship with himself and for fellowship with fellow human beings ${ }^{56}$ According to Barth, sin did not affect the image of God. The image of God in man remains unchangeable, regardless of the fall or sin (Gen 3),

We certainly cannot deduce from this [the fall] that man has lost it through the fall, either partially or completely, formally or materially. ${ }^{57}$

The fall or sin concealed man's nature from himself and his fellow human beings, but not from God. According to Barth, man learns about his nature by studying Christ: 'As the man, Jesus is revealing himself the revealing Word of God, he is the source of our knowledge of the nature of man as created by God. ${ }^{58}$ This does not mean that we, as human beings, can equate our human nature with that of Jesus Christ, ${ }^{59}$ for he is superior to us by far and his humanity is pure in form and he is the full image of God. ${ }^{60}$

Westermann shares a similar view to that of Barth. He sees the image and likeness of God in Genesis 1:26-27 as consisting of the relationship between God and man.

51 Von Rad, G. 1972. Genesis, 58. Also cited in Jónsson. Gunnlaugur, A. The image of God: Genesis 1:26-28, 96.

52 Von Rad, G. 1972. Genesis, 59.

53 Barth, K. 1960a. Church dogmatics, III/1. Edited by G.W. Bromiley and T.F. Torrance. Edinburgh: $\mathrm{T}$ and T Clark, 184-185. Also cited in Jónsson, Gunnlaugur, A. The image of God: Genesis 1:2628, 73.

54 Barth, K. 1960a Church dogmatics, III/1, 184

55 Barth, K. 1960a. Church dogmatics, III/1, 184

56 Barth, K. 1960b Church dogmatics, III/2. Edited by G.W. Bromiley and T.F. Torrance. Edinburgh: T and T Clark, 203.

57 Barth, K.1960a. Church dogmatics, III/1, 200.

58 Barth, K. 1960b. Church dogmatics, III/2, 41.

59 Barth, K. 1960b. Church dogmatics, III/2, 41.

60 Barth, K. 1960b. Church dogmatics, III/2, 225. 
He says that God created man so that he can have a relationship with him just as in the Sumerian and Babylonian texts, where people were related to the creator god as servants of the gods. ${ }^{61}$ Westermann writes, 'humans are created in such a way that their very existence is intended to be their relationship to God'. ${ }^{62}$ Like Barth, Westermann says that man has an interactive relationship with God. Man is God's counterpart, a creature that corresponds, speaks and listens to God. ${ }^{63}$ In support of his view, Westermann points out that Genesis 1:26ff with its pre-history is derived from an independent circulative narrative parallel to Genesis 2, not originally part of the creation account. ${ }^{64}$ So to him, Genesis 1:26-27 has nothing to do with creation. The major concern of Genesis 1:26-27 and Genesis 2 is the relationship between God and human beings. Commenting on Genesis 1:26, Westermann says, as if it is common knowledge, that "what is striking is that one verse about a person, almost unique in the Old Testament, has become the center of attention in modern exegesis, whereas it has no such significance in the rest of the Old Testament, and, apart from Ps 8, does not occur again'; 65 'Gen 1:26f. is not making a general and universal valid statement about the nature of humankind; if it were, then the Old Testament would have much more to say about this image and likeness. ${ }^{66}$ Westermann does not make some sort of weighty argument to support his position.

\section{Functional views}

Clines interprets the image and likeness of God in Genesis 1:26-27 from a strictly functional perspective, in which the image of God in man is the visible corporeal representative of the invisible, bodiless God. ${ }^{67}$ Man functions as a representative (not a representation) in his exercise of dominion:

The image is to be understood not so much ontologically as existentially: it comes to expression not in the nature of man so much as in his activity and function. This function is to represent God's lordship to the lower orders of creation. The dominion of man over creation can hardly be excluded from the content of the image itself. ${ }^{68}$

Clines thinks that there is nothing in the context of Genesis 1:26-27 which gives meaning to the image of God; rather he sees the Ancient Near Eastern concept of the

61 Westermann, C. 1987. Genesis 1-11: A commentary. Minneapolis: Augsburg, 157-158. Also cited in Gunnlaugur, A. Jónsson. The image of God: Genesis 1:26-28, 165.

62 Westermann, C. 1987. Genesis 1-11, 158.

63 Westermann, C. 1987. Genesis 1-11, 157.

64 Westermann, C. 1987. Genesis 1-11, 157. Also cited in Jónsson, Gunnlaugur, A. The image of God: Genesis 1:26-28, 162.

65 Westermann, Claus. 1987. Genesis 1-11, 148.

66 Westermann, Claus. 1987. Genesis 1-11, 155.

67 Clines, D.J.A. 1968. The image of God in man. Tyndale Bulletin 19: 87-88.

68 Clines, D.J.A. 1968. The image of God in man, 101. 
image of a god as the key to the interpretation of the image of God in Genesis 1:26$27 .{ }^{69}$ In the Ancient Near East, the image functioned as a kind of representative of or a substitute for a god wherever it was located, and certain individuals (especially the kings) were regarded as representatives of various gods and they ruled on their behalf. ${ }^{70}$ Clines sees the same idea behind the concept of the image of God in Genesis 1:26-27. According to Clines, the fall did not affect the image and likeness of God. Mankind does not cease to be the image of God as long as they are men, 'to be human and to be the image of God are inseparable'. ${ }^{71}$

When he comes to the New Testament, Clines sees a change of interpretation to a substantive view. ${ }^{72}$ The image of God is seen in connection with Christ, the Second Adam, who is the true and perfect image of God. Christ is the 'image of the invisible God' (Col 1:15). Christ is the logos the image, who reflects the glory of God and bears the very character of God. Christ is the head of the new community of believers. The image of Christ, rather than the image of God, comes to the forefront when the believer's conformity with the image is spoken of. Bearing the image of Christ is an eschatological concept. The complete conformity with the image of Christ will be fully attained at the end of the age when the believer is glorified. Man is God's representative on earth. Christ in a sensus plenior is God's 'one' representative on earth and the community of believers becomes the dwelling-place of God on earth. In Christ, man sees what being human was meant to be. Man is in God's image in the New Testament as long as he is like Christ. Clines's understanding of the image of God in the New Testament is not functional, but substantive. He says that the believer is transformed and becomes more and more like Christ in character. The believer is progressively renewed into the image of Christ (Col 3:10-11). The full image of God is realised only through obedience to Christ. This is how man becomes fully man, thus being in the image of God. ${ }^{73}$

Ian Hart agrees with the view of Clines of the image and likeness of God in Genesis 1:26-27. ${ }^{74}$ Like Clines, he sees the image as the function of dominion and he is also convinced that the Scriptures support this functional view. ${ }^{75}$ He argues that the two phrases in Genesis 1:26, 'Let us make man in our image' and 'let them have dominion...the earth' should be connected not by 'and' but 'so that', because when a simple vav is followed by an imperfect it usually expresses the purpose of

69 Clines, D.J.A. 1968. The image of God in man, 80-85.

70 Clines, D.J.A. 1968. The image of God in man, 81-85.

71 Clines, D.J.A. 1968. The image of God in man, 99-101.

72 Clines, D.J.A. 1968. The image of God in man, 102.

73 Clines, D.J.A. 1993. Image of God. In Dictionary of Paul and his letters: A compendium of contemporary biblical scholarship. Edited by G.F. Hawthorne. Illinois: Downers Grove, 427.

74 Hart, I. 1995.Genesis 1:1-2:3 as a prologue to the Book of Genesis. Tyndale Bulletin 46(2 Nov): 317-319.

75 Hart, I. 1995.Genesis 1:1-2:3 as a prologue to the Book of Genesis, 317-319. 
the preceding verb. ${ }^{76}$ Therefore, he suggests that Genesis 1:26 should be translated as 'Let us make man in our image, according to our likeness, so that they may have dominion over...the earth' [emphasis added]. Hart also cites Psalm 8:5 to support his view. He says that because man is created a little lower than God, he is God's representative. According to Hart, the idea of the image of God was democratised in Israel. The Egyptian and Mesopotamian (or ANE) concept of a king being in a god's image was broadened to make mankind in general in such an image.

The 1983 Bible translation in Afrikaans opted for the functional view rather than a free translation of Genesis 1:26-27. 'Man is God's 'verteenwoordiger" [representative].

Richard J. Middleton interprets the image and likeness of God in Genesis 1:2627 from a functional or 'Royal' perspective..$^{77}$ According to Middleton the 'royal' flavour of the text 'does not depend only on the close linking of image with the mandate to rule and subdue the earth and its creatures in verses 26 and 28 (typically royal functions). Beyond this royal mandate, the God in whose image and likeness humans are created is depicted as sovereign over the cosmos, ruling by royal decree ("let there be"). ${ }^{78}$ Middleton argues that Genesis 1:26 is parallel to Isaiah 6: in both cases God is addressing the heavenly court. In Genesis 1:26, God addresses his court with the words 'let us make humanity in our image'; an address which is parallel to God's question to the seraphim in Isaiah 6:8: 'Whom shall I send? And who will go for us.' Just as Isaiah saw Yahweh 'seated on a throne, high and exalted' (Isa 6:1), so the author of Genesis 1 portrays God as King over the heavens and the earth. ${ }^{79}$ According to Middleton, the immediate context of Genesis 1:26-27 does not clarify the meaning of the imago Dei, so he views the Ancient Near East as the background of the imago Dei. ${ }^{80}$ According to Middleton, the imago Dei 'designates the royal office or calling of human beings as God's representatives and agents in the world, granted authorised power to share in God's rule or administration of the earth's resources and creatures' ${ }^{81}$ Middleton sees the creation account of Genesis 1 as a polemic against the ancient Near Eastern polytheism. ${ }^{82}$ According to Middleton, Genesis 1:26-27 'was intended to subvert as an oppressive social system and to empower' God's people with dignity as God's representatives in the world. ${ }^{83}$

76 See Lambdin, O.T. 1971. Introduction to biblical Hebrew. New York: Charles Scribner, 119.

77 Middleton, R.J. 1994. The liberating image? Interpreting the imago Dei in context. Christian Scholars Review 24(1): 8.

78 Middleton, R.J. 1994. The liberating image? Interpreting the imago Dei in context. Christian Scholars Review 24(1):12.

79 Middleton, R.J. 1994. The liberating image? 12.

80 Middleton, R.J. 2005. The liberating image: The imago Dei in Genesis. Peabody: Brazos Press, 93-185.

81 Middleton, R.J. 1994. The liberating image: The imago Dei in Genesis, 27.

82 Middleton, R.J. 1994. The liberating image? 17-21.

83 Middleton, R.J. 1994. The liberating image? 21-22. 
When he comes to the New Testament, Middleton sees Jesus Christ as portrayed as the image of God par excellence (Col 1:15; Heb 1:3; 2 Cor 4:4-6). The term Messiah or Christ was understood as a royal designation. Jesus explicitly exemplifies what is implicit in Genesis 1 and explicit in the Old Testament, "namely that the right use of power is not oppressive control of others, but their liberation or empowerment' ${ }^{84}$ The church inherits Christ's representative task. The church is renewed in the imago Dei (Eph 4:24; Col 3:9-11; 2 Cor 3:17-18), is sent by Christ and is called to imitate Christ's paradigm of self-giving, thus witnessing to God's rule in its communal life. ${ }^{85}$

\section{A COMBINATION OF TWO OR THREE VIEWS}

Berkouwer interprets the image and likeness of God in Genesis 1:26-27 from relational and substantive perspectives. He says that the image of God primarily denotes man's relationship to God, but this relationship to God includes a moral likeness to God. Man is unique because he can relate to God; this is the image of God. ${ }^{86}$ According to Berkouwer, when man fell into sin, the image of God in man was affected, part of the image of God was lost and the other part was retained. The fallen man is still man. ${ }^{87}$ Like Calvin, Berkouwer points out that the New Testament sheds light on the meaning of the image of God. Firstly, by what it says about the restoration of the image of God in the lives of believers; and secondly, by what it says about Christ, who is the image of God. ${ }^{88}$ Through sanctification, believers are renewed into the image of God, and this manifests itself in 'the fullness of the new life, which can be described as a new relationship with God, and in this relationship as the reality of salvation'. ${ }^{89}$ In Berkouwer's understanding, this new life is a life in conformity to the will of God, a life of newness, fellowship, and joy..$^{90}$ The believer becomes more and more like Christ in character. Morally, he becomes like Christ. The believer should constantly strive to be like God in God's strength each day of his life (Eph 5:1-2). The renewal of man into the image of God is a product of God's redemptive work. According to Berkouwer, man will fully reflect the image of God in the life to come. ${ }^{91}$ From the above discussion, Berkouwer's interpretation of the image and likeness of God (Gen 1:26-27) seems to be mainly influenced by the New Testament Scriptures.

84 Middleton, R.J. 1994. The liberating image? 23-24.

85 Middleton, R.J. 1994. The liberating image? 24.

86 Berkouwer, G.C. 1962. Studies in dogmatics: Man: the image of God. Grand Rapids: Eerdmans, 34-35.

87 Berkouwer, G.C. 1962. Man: the image of God, 119-120.

88 Berkouwer, G.C. 1962. Man: the image of God, 87-89.

89 Berkouwer, G.C. 1962. Man: the image of God, 99.

90 Berkouwer, G.C. 1962. Man: the image of God, 98-104.

91 Berkouwer, G.C. 1962. Man: the image of God, 104-112. 
Meredith G. Kline views the image of God in Genesis 1:26-27 from functional, substantive, and relational perspectives. The functional aspect of the image of God consists of man's likeness to God in having authority and exercising dominion. The substantive aspect of the image of God consists of ethical characteristics or attributes of God, thus holiness, righteousness, and truth. As well as the formal-physical glory likeness, man's physical body reflects the glory of God (not the body of God). At creation, man was made 'a little lower than the angels' (Ps 8:5) and he was crowned with glory and honour in the likeness of the enthroned Glory. ${ }^{92}$ Therefore, Kline views the image and glory as twin models, which express man's likeness to the divine Original. ${ }^{93}$ The relational aspect of the image of God is seen in the father-son relationship between God and man. 'To be in the image of God is to be a son of God. ${ }^{94}$ Kline writes:

Adam's fathering of a son [in his image and likeness, Genesis 5:3] provides a proper analogy to God's creating of man and the relationship of Seth to Adam is analogous to man's relationship to his Maker. ${ }^{95}$

Kline argues that the same notion is seen in Luke's genealogy (Luke 3:38), where Luke traces Jesus' lineage back to Adam, who is called the son of God. The origin of the second Adam (Jesus Christ) is attributed to the overshadowing presence and power of the Glory-Spirit. ${ }^{96}$

Under the concept of man as the glory-image of God, the Bible includes functional (or official), formal (or physical), and ethical components, corresponding to the composition of the archetypal Glory. ${ }^{97}$

According to Kline, the ethical likeness to God (or ethical Glory) that belonged to man was corrupted by the fall, when man fell into sin (cf. Rom 3:23). Man was stripped of righteousness, holiness, and love of the truth. Man's original condition can only be restored by divine grace. By common grace, a measure of the gloryimage was being preserved in spite of the fall. The image of God in man is restored through sanctification (which is the work of the Spirit) where man is re-created after the image of God in true knowledge, righteousness, and holiness (Eph 4:24; Col 3:10). ${ }^{98}$ With respect to this ethical glory-likeness to God, the Spirit of the Lord transforms man from glory to glory (2 Cor 3:18; 4:16; Rom 12:2). Man is restored to the hope of the formal-physical image-glory of resurrection immortality and spiritual

92 Kline, M.G. 1980. Images of the Spirit. Grand Rapids: Baker, 31; Kline, M.G. 1993. Kingdom Prologue. Hamilton: n. p., 30.

93 Kline, M.G. 1980. Images of the Spirit, 30-31.

94 Kline, M.G. 1993. Kingdom Prologue, 30.

95 Kline, M.G. 1993. Kingdom Prologue, 30.

96 Kline, M.G. 1993. Kingdom Prologue, 30.

97 Kline, M.G. 1980. Images of the Spirit, 31.

98 Kline, M.G. 1980. Images of the Spirit, 32. 
existence. ${ }^{99}$ Man will possess the full image of God when he is glorified (when the kingdom of God is consummated) and this eschatological glorification will transform man into a transfigured glory, the image of the radiant Glory-Spirit. ${ }^{100}$

Edward M. Curtis interprets the image and likeness of God in Genesis 1:26-27 from the relational and functional perspectives. ${ }^{101} \mathrm{He}$ says that man is capable of relating to God. Like Kline, he points out that Adam's fathering a son in his image and likeness (Gen 5:3) provides a good analogy to God's creation of man, and Seth's relationship to his father, Adam, is analogous to Adam's relationship to God. Curtis writes:

Genesis 5:3 reports that Adam fathered a son "in his likeness, according to his image". This suggests that the way in which the son resembles the father is in some sense analogous to the way in which the human is like God. ${ }^{102}$

Curtis says that it is possible to deduce from this analogy (father-son relationship) that the image of God in man is also functional. The son is the image of his father because he functions like his father and on behalf of his father. Like Clines, Curtis also views the image of God in man as the visible corporeal representative of God and man functions as a representative of God in his exercise of dominion. Like Clines, he thinks that there is nothing in the context of Genesis 1:26-27 which gives meaning to the image of God; rather, he sees the Ancient Near Eastern concept of the image of a god as the key to the interpretation of the image of God in Genesis 1:26-27. Because the image functioned as a kind of representative of or a substitute for a god wherever it was located in the Ancient Near East and certain individuals, especially kings, were regarded as representatives of gods and they ruled on their behalf, Curtis thinks that idea of the image of God probably originated in Egypt and was borrowed by the Israelites during their settlement in Egypt and they transformed it to suit their theology. ${ }^{103}$

Daniel Simango sees Genesis 1-11 as the context in which the imago Dei (Gen 1: 26-27) is to be examined. ${ }^{104}$ Simango views the image of God in Genesis 1:26-27 from the substantive and relational perspectives: it involves moral likeness to God and a relationship between God and human kind like that between parent and child. Humans' relationship to God was based on trust, faith, love, dependence, and obedience. They were tempted and they fell into sin, the moral and relational aspects of the image of God were corrupted. Morally, humankind is like the serpent,

99 Kline, M.G. 1980. Images of the Spirit, 32.

100 Kline, M.G. 1993. Kingdom Prologue, 29.

101 Curtis, E.M. 1992. Image of God (OT). Vol. 3. In Anchor Bible Dictionary. Edited by D.N. Freedman. New York: Doubleday, 390-391.

102 Curtis, E.M. 1992. Image of God (OT), 390.

103 Curtis, E.M. 1992. Image of God (OT), 390-391.

104 Simango, D. 2012. The meaning of the imago Dei in Genesis 1-11. Old Testament Essays 25(3): 640-641. 
for example, Cain and Ham. Relationally, humankind is seen as the offspring of the serpent and enslaved to sin (e.g. Cain and the wicked in general). ${ }^{105}$ However, humankind is also renewed into the image of God through a creative act of God. For example, Abel is like light, God's new creation. He is a righteous man. He is seen as the regenerate man. ${ }^{106}$ The image of God was not totally defaced by the Fall, yet despite the corruption, part of the image of God still remains in human kind. ${ }^{107}$ Like Von Rad, ${ }^{108}$ Simango views dominion or ruling as a consequence of being in the image of God, and not the essence of the divine image. ${ }^{109}$ Simango also argues that the substantive, relational and functional aspects of the image of God are also brought out in the narrative and legal sections of the Pentateuch. General statements, for example, the overall summary of the law found in Leviticus 19:2 ('You shall be holy, for I the Lord your God am holy'), suggest defining God-likeness (morally) is one of the purposes of the law. ${ }^{110}$ The Israelites are portrayed as God's children. This implies they are in his image since sonship implies image. ${ }^{111}$ Passages in the law speak of dominion for Israel in a way that suggests that dominion is the consequence of Israel being in the image of God. ${ }^{112}$

When he comes to the New Testament, Simango sees Jesus Christ as the Son of God and the perfect expression of the image of God. ${ }^{113}$ Christ is equal to God in essence. ${ }^{114}$ Through his work on the cross, believers are adopted as God's children and are to be morally like him. ${ }^{115}$ Believers are called to be like Christ. They are to imitate Christ's moral-likeness and submission to the Father. ${ }^{116}$

\section{SUMMARY OF RECENT INTERPRETATIONS OF THE IMAGE OF GOD (GEN 1:26-27)}

The modern period shows a wide range of opinion regarding the image of God. The image and likeness of God in Genesis 1:26-27 are interpreted from the functional, relational, and substantive perspectives or a combination of these. The image of God is seen as having dominion over creation (Gen 1:28), having fellowship with

105 Simango, D. 2012. The meaning of the imago Dei in Genesis 1-11, 641-644.

106 Simango, D. 2012. The meaning of the imago Dei in Genesis 1-11, 644-647.

107 Simango, D. 2012. The meaning of the imago Dei in Genesis 1-11, 650.

108 Von Rad, G. 1972. Genesis, 59.

109 Simango, D. 2006. The image of God (Gen 1:26-27) in the Pentateuch: A biblical-theological approach. North-West University, MA dissertation, 3, 33, 34, 39, 56, 61, 79, 84, 85, 103, 104, 105.

110 Simango, D. 2006. The image of God (Gen 1:26-27) in the Pentateuch, 69-74.

111 Simango, D. 2006. The image of God (Gen 1:26-27) in the Pentateuch, 62-64.

112 Simango, D. 2006. The image of God (Gen 1:26-27) in the Pentateuch, 84-85.

113 Simango, D. 2006. The image of God (Gen 1:26-27) in the Pentateuch, 89-92.

114 Simango, D. 2006. The image of God (Gen 1:26-27) in the Pentateuch, 93.

115 Simango, D. 2006. The image of God (Gen 1:26-27) in the Pentateuch, 93-98.

116 Simango, D. 2006. The image of God (Gen 1:26-27) in the Pentateuch, 98-101. 
God, as consisting of corporeal resemblance, denoting the bodily form, as well as spiritual, psychological, and moral attributes or qualities. From the history of recent interpretation, it is evident that most interpreters and commentators do not think that the biblical context of Genesis 1:26-27 is sufficient to define what it means to be created in the image of God. Many commentators interpret the image of God from a New Testament perspective in which Christ restores the image of God in man, (not attempting any Old Testament development of the theme) to justify their interpretation of the image of God that may be substantive, relational, functional or a combination of these.

Although there is a wide range of interpretations of what the image of God refers to, many commentators and scholars agree that Christ is the perfect or true image of God. He is the second Adam, who restores the corrupted or distorted image in man; this happens when he is regenerated and sanctified through a personal relationship with Jesus Christ.

\section{CONCLUSION}

Philo, Irenaeus, Augustine, and Aquinas interpreted the image of God in man as the power of reason. Luther and Calvin interpreted the image of God in man as moral likeness to God. The fall corrupted the image of God and redemption restores the shattered image of God. The modern period shows a wide range of opinions regarding the image of God. The image and likeness of God in Genesis 1:26-27 are interpreted from the functional, relational and substantive perspectives or a combination of these.

\section{REFERENCES}

Althaus, P. 1966. The theology of Martin Luther. Philadelphia: Fortress Press.

Aquinas, T. 1952. The Summa Theologica 1. In Great books of the Western world. Edited by H.R. Maynard. London: William Benton, Vol. 19.

Augustine. 1961. The confessions of Saint Augustine. London: Penguin.

Augustine. 1988. St Augustine: On the Holy Trinity; doctrinal treatises; moral treatises. In Nicene and Post-Nicene Fathers. Edited by P. Schaff. Grand Rapids: Eerdmans, 3:95-190.

Barth, K. 1960a. Church dogmatics, III/1. Edited by G.W. Bromiley and T.F. Torrance. Edinburgh: $\mathrm{T}$ and T Clark.

Barth, K. 1960b. Church dogmatics, III/2. Edited by G.W. Bromiley and T.F. Torrance. Edinburgh: $\mathrm{T}$ and T Clark.

Berkouwer, G.C. 1962. Studies in dogmatics: Man: the image of God. Grand Rapids: Eerdmans. Bible. 1983. Die Bybel. Kaapstad: Die Bybel Genootskap van Suid-Afrika.

Blocher, H. 1984. In the beginning: The opening chapters of Genesis. Leicester: Inter-Varsity Press. 
Brunner, E. 1952. The Christian doctrine of creation and redemption. Philadelphia: Westminster Press.

Cairns, D. 1953. The image of God in man (Revised edition). London: Collins.

Calvin, J. 1960. The institute of the Christian religion. Edited by J.T. McNeill. Philadelphia: Westminster.

Calvin, J. 1979a. Calvin's commentaries Vol 1: Genesis. Grand Rapids: Baker.

Calvin, J. 1979b. Calvin's commentaries Vol XX1: Ephesians. Grand Rapids: Baker.

Calvin, J. 1979c. Calvin's commentaries Vol 1: Colossians. Grand Rapids: Baker.

Clines, D.J.A. 1986. The image of God in man. Tyndale Bulletin 19: 53-104.

Clines, D.J.A. 1993. Image of God. In Dictionary of Paul and his letters: A compendium of contemporary biblical scholarship. Edited by G.F. Hawthorne. Illinois: Downers Grove, 426-428.

Curtis, E.M. 1992.Image of God (OT). In Anchor Bible Dictionary, Vol 3, 389-391. Edited by D.N. Freedman. New York: Doubleday.

De Lacey, D.R. 1979. Image and incarnation in Pauline Christology: A search for origins. Tyndale Bulletin (TB) 30: 3-28.

Dillman, A. 1897. Genesis: Critically and exegetically expounded. Edinburgh: T. and T. Clark.

Hart, I. 1995. Genesis 1:1-2:3 as a prologue to the Book of Genesis. Tyndale Bulletin 46(2): 315336.

Hoekema, A. 1986. Created in God's image. Grand Rapids: Eerdmans.

Irenaeus. Against Heresies. 1953. In Ante-Nicene Fathers. Edited by A. Roberts and J. Donaldson. Grand Rapids: Eerdmans, 1:315-567.

Jónsson, G.A. 1988. The image of God: Genesis 1:26-28 in a century of Old Testament research. Lund: Almqvist and Wiksell.

Keil C.F. and Delitzsch, F. 1987. Commentary on the Old Testament in ten volumes. Volume 1. The Pentateuch: three volumes in one. Grand Rapids: Eerdmans.

Kline, M.G. 1980. Images of the Spirit. Grand Rapids: Baker.

Kline, M.G. 1993. Kingdom prologue. Hamilton, MA, no publisher.

Lambdin, O.T. 1971. Introduction to biblical Hebrew. New York: Charles Scribner.

Luther, M. 1985. Luther's works Vol 1: Lectures on Genesis chapters. Edited by J. Pelikan. St. Louis: Concordia. McCasland, S.V. 1950. The image of God according to St. Paul. Journal of Biblical Literature (JBL) 69: 85-100.

Middleton, R.J. 1994. The liberating image? Interpreting the imago Dei in context. Christian Scholars Review 24(1): 8-25.

Middleton, R.J. 2005. The liberating image: The imago Dei in Genesis Grand Rapids: Brazos Press.

Miller, J.M. 1972. In the image and likeness of God. Journal of Biblical Literature (JBL), 91: 289-304.

Philo.1993. The works of Philo (New updated edition, complete and unabridged in one volume). Peabody: Hendrickson. 
Simango, D. 2006. The image of God (Gen 1:26-27) in the Pentateuch: A biblical-theological approach. North-West University, MA dissertation.

Simango, D .2012. The meaning of the imago Dei (Gen 1:26-27) in Genesis 1-11. OTE 25(3): 638-656.

Skinner, J. 1930. A critical and exegetical commentary on Genesis. International Critical Commentary. Edinburgh: T and T Clark. Von Rad, G. 1972. Genesis: A commentary. Old Testament Library. London: SCM Press.

Westermann, C. 1987. Genesis 1-11: A commentary. Minneapolis: Augsburg. 